\title{
Penegakan Hukum oleh Kepolisian Resor Langkat terhadap Pembalakan Liar (Illegal Logging) di Wilayah Hukum Polres Langkat
}

\section{Law Enforcement by the Langkat Resort Police against Illegal Logging in the Langkat Police Legal Area}

\author{
Herman Frenky Sinaga1), Ediwarman') \& M. Citra Ramdhan1) * \\ Program Studi Magister Ilmu Hukum, Universitas Medan Area Indonesia \\ Fakultas Hukum, Universitas Sumatera Utara, Indonesia
}

Diterima: 13 Juni 2021; Direview: 02 Agustus 2021; Disetujui: 07 Oktober 2021

*Coresponding Email: citra@staff.uma.ac.id

\begin{abstract}
Abstrak
Aktivitas manusia yang mengakibatkan kerusakan lingkungan hidup salah satunya ialah pembalakan liar atau illegal logging, yang merupakan tindakan eksploitasi oleh manusia terhadap hutan sehingga menimbulkan kerusakan terhadap ekosistem hutan. Penelitian ini bertujuan untuk mengetaui faktor penyebab terjadinya pembalakan liar di wilayah hukum Polres Langkat serta kebijakan yang dilakukan Kepolisian dalam penegakan hukum terhadap pembalakan liar di wilayah hukum Polres Langkat. Metode penelitian yang digunakan adalah metode deskriptif, dengan menggunakan teknik analisis data deskriptif kualitatif. Hasil penelitian menunjukkan bahwa faktor-faktor yang menyebabkan terjadinya pembalakan liar di Kabupaten Langkat adalah Faktor intern, terdiri dari faktor ekonomi dan faktor kurangnya kesadaran masyarakat terhadap lingkungan, dan faktor ekstern, terdiri dari faktor harga kayu mahal, kebutuhan kayu tinggi, pengawasan yang lemah, penegakan hukum kurang tegas. Kebijakan yang dilakukan oleh Polres Langkat dalam penegakan hukum terhadap tindak pidana pembalakan liar terdiri dari kebijakan penal yaitu laporan pembalakan liar, menindaklanjuti pembalakan liar, terjum ke lokasi pembalakan liar, mengamankan barang bukti, menangkap truk kayu illegal. Kebijakan non penal yaitu sosialisasi larangan pembalakan liar, meningkatkan partisipasi masyarakat, mengawasi truk-truk kayu, pemeriksaan tersangka, pengembangan kasus, pelimpahan berkas.
\end{abstract}

Kata Kunci: Kepolisian; Penegakan Hukum; Pembalakan Liar;

\begin{abstract}
Human activities that cause environmental damage, one of which is illegal logging or illegal logging, which is an act of exploitation by humans on forests, causing damage to forest ecosystems. This study aims to determine the factors that cause illegal logging in the Langkat Police jurisdiction and the policies carried out by the Police in law enforcement against illegal logging in the Langkat Police jurisdiction. The research method used is descriptive method, using qualitative descriptive data analysis techniques. The results showed that the factors that caused illegal logging in Langkat Regency were internal factors, consisting of economic factors and the lack of public awareness of the environment, and external factors, consisting of high wood prices, high wood demand, weak supervision, law enforcement is not strict. The policies carried out by the Langkat Police in law enforcement against the crime of illegal logging consist of penal policies, namely reporting illegal logging, following up on illegal logging, going to illegal logging locations, securing evidence, catching illegal timber trucks. Non-penal policies include socializing the prohibition of illegal logging, increasing community participation, supervising timber trucks, examining suspects, developing cases, and transferring files.
\end{abstract}

Keywords: Police; Law enforcement; Illegal logging;

How to Cite: Sinaga, H.F., Ediwarman., \& Ramadhan, M.C. (2021). Penegakan Hukum oleh Kepolisian Resor Langkat terhadap Pembalakan Liar (Illegal Logging) di Wilayah Hukum Polres Langkat. Journal of Education, Humaniora and Social Sciences (JEHSS). 4 (2): 1047-1056. 


\section{PENDAHULUAN}

Lingkungan hidup merupakan tempat yang sangat vital bagi manusia, karena lingkungan hidup telah menjadi tempat sehari-hari untuk berdiam (tempat tinggal) serta tempat untuk memperoleh penghidupan yang layak (Siregar, 2020). Bumi atau lingkungan hidup adalah sumber kehidupan fisik manusia dan juga tempat manusia melakukan berbagai hal yang berhubungan dengan kehidupan. Sedemikian pentingnya peranan lingkungan hidup bagi manusia sehingga dapat dikatakan bahwa tanpa lingkungan hidup yang baik atau layak maka kehidupan manusia akan menjadi sengsara.

Secara definisi, lingkungan hidup adalah kesatuan ruang dengan semua benda, daya, keadaan, dan makhluk hidup, termasuk manusia dan perilakunya, yang mempengaruhi alam itu sendiri, kelangsungan perikehidupan, dan kesejahteraan manusia serta makhluk hidup lain (Armawi, 2013). Artinya bahwa lingkungan hidup serta semua benda didalamnya tidak dapat dipisahkan satu sama lain sebagai bagian dari hidup manusia, sehingga harus dilakukan pemeriharaan bersama agar setiap bagian yang ada didalamnya dapat berperan sesuai dengan fungsinya dalam ekosistem lingkungan.

Namun seiring dengan perkembangan zaman maka lingkungan hidup juga mengalami perubahan yang sangat besar, dimana perubahan tersebut mengarah pada kondisi yang tidak baik bagi kehidupan manusia. Penyebab utama dari perubahan tersebut adalah keinginan manusia yang tidak terbatas untuk melakukan eksploitasi besar-besaran (Sunarso, 2015). Manusia melalui berbagai teknologi yang diciptakannya telah melakukan eksploitasi secara berlebihan terhadap bumi dan segala isinya dengan tujuan untuk memperoleh keuntungan jangka pendek yang sebesar-besarnya. Manusia menginginkan keuntungan yang melebihi kebutuhan hidupnya, sehingga terjadi eksploitasi tanpa memperdulikan akibatnya terhadap lingkungan hidup, sehingga menimbulkan perusakan dan pencemaran lingkungan hidup(Rosana, 2018).

Salah satu aktivitas manusia yang mengakibatkan kerusakan lingkungan hidup adalah pembalakan liar atau illegal logging, yang merupakan tindakan eksploitasi oleh manusia terhadap hutan sehingga menimbulkan kerusakan terhadap ekosistem hutan. Berdasarkan definisinya, perusakan hutan adalah proses, cara, atau perbuatan merusak hutan melalui kegiatan pembalakan liar, penggunaan kawasan hutan tanpa izin atau penggunaan izin yang bertentangan dengan maksud dan tujuan pemberian izin di dalam kawasan hutan yang telah ditetapkan, yang telah ditunjuk, ataupun yang sedang diproses penetapannya oleh Pemerintah. Sedangkan pembalakan liar adalah semua kegiatan pemanfaatan hasil hutan kayu secara tidak sah yang terorganisasi.

Perusakan hutan akibat pembalakan liar tentu akan mengganggu lingkungan hidup, karena hutan memiliki peran penting sebagai paru-paru dunia, habitat flora dan fauna, serta pengendali bencana (Prabowo \& Absori, 2018). Pohon-pohon di hutan berperan menyerap karbondioksida dan mengeluarkan oksigen yang dibutuhkan semua organisme, sehingga keberadaan pohon dan hutan akan membuat udara menjadi lebih sehat untuk dihirup, serta menjaga suhu bumi dan keseimbangan alam. Disamping itu, keberadaan pohon juga menjadi pengendali bencana banjir dan longsor, karena penyerapan air ke dalam tanah lebih optimal sehinga bencana banjir bisa diminimalisir, dan akarnya juga dapat menahan tanah agar tidak terjadi bencana longsor. Tetapi jika luas hutan terus menyusut karena pembalakan liar maka fungsi hutan juga tidak dapat berjalan secara maksimal sehingga dapat menimbulkan bahaya bagi kehidupan manusia.

Menurut data Departemen Kehutanan tahun 2006, luas hutan yang rusak dan tidak dapat berfungsi optimal telah mencapai 59,6 juta hektar dari 120,35 juta hektare kawasan hutan di Indonesia, dengan laju deforestasi dalam lima tahun terakhir mencapai 2,83 juta hektar per tahun. Demikian juga dari hasil penelitian Greenpeace mencatat tingkat kerusakan hutan di Indonesia mencapai angka 3,8 juta hektare pertahun, yang sebagian besar disebabkan oleh aktivitas illegal logging atau penebangan liar.

Hasil survey yang dilakukan pemerintah menyebutkan bahwa tutupan hutan pada tahun 1985 mencapai 119 juta hektare. Bila dibandingkan dengan luas hutan tahun 1950 mengalami penurunan 27 persen. Antara tahun 1970 an dan 1900 an laju menghilangnya lahan hutan diperkirakan antara 0,6 dan 1,2 juta hektare. Pada periode tahun 1997 - 2000 ditemukan fakta penyusutan hutan meningkat menjadi 3,8 juta hektare pertahun. Hilangnya hutan seluas itu 10 http://mahesainstitute.web.id/ojs2/index.php/jehss 1048

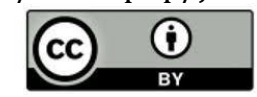

This work is licensed under a Creative Commons Attribution 4.0 
disebabkan tidak dipatuhinya ketentuan hukum oleh pemengang izin Hak Penguasaan Hutan (HPH). Salah Satu kewajiban yang dilalaikannya, adalah tidak melaksanakan Sistem Tebang Pilih Indonesia (TPI) dalam mengeksplotasi hutan. TPI merupakan suatu sitem di mana setiap pemengang izin HPH harus melakukan penebangan kayu dengan diameter berukuran $55-85 \mathrm{~cm}$ atau rata - rata $70 \mathrm{~cm}$. Disamping itu, pemegang izin $\mathrm{HPH}$ diharuskan melakukan penyuburan dengan bibit kayu perdagangan, serta diadakan pembebasan dan peremejaan jenis - jenis kayu perdagangan dari tumbuh - tumbuhan penganggu, namun yang mereka lakukan adalah penebangan kayu dengan Sistem Tebang Habis (STH) di mana kayu yang berdiameter kurang dari $55-85 \mathrm{~cm}$ juga ikut ditebang. Akibatnya, lokasi hutan pemengang izin HPH banyak yang rusak sebagaimana yang diungkapkan FAO.

Selain itu rusaknya hutan karena banyaknya orang yang melakukan pencurian kayu di kawasan hutan, baik hutan lindung, hutan produksi, maupun hutan lainnya. Pencurian kayu dilakukan dengan menggunakan alat tradisional (seperti kapak dan parang), dan alat - alat modern, seperti gergaji mesin berantai. Penggunaan gergaji mesin berantai ini mempercepat proses rusaknya hutan karena di dalam pencurian tersebut jenis kayu yang ditebang tidak dikontrol (Rahman \& Mulada, 2020). Sehingga kayu yang berukuran kecil pun ditebang oleh pencuri kayu dengan sewenang - wenang. Hutan sebagai bagian dari sumber daya alam nasional memiliki arti dan peranan penting dalam berbagai aspek kehidupan sosial, pembangunan dan lingkungan hidup telah diterima sebagai kesepakatan internasional bahwa hutan yang berfungsi penting bagi kehidupan dunia, harus dibina dan dilindungi dari berbagai tindakan yang berakibat rusaknya ekositem dunia.6 Hutan - hutan Indonesia mengandung keanekaragaman hayati flora dan fauna yang tinggi, termasuk 10 persen dari tanaman dunia, 12 persen dari mamalia dunia, 16 persen dari reptil-amfibi dunia dan 17 persen dari spesies burung dunia, menurut studi tersebut, yang dimuat dalam jurnal Nature Climate Change. Penebangan pohon di hutan primer Indonesia yang ekstensif menyebabkan hilangnya habitat dan punahnya tanaman dan tumbuhan. Berdasarkan data rekapitulasi data penaggulan kasus selama 2019 kasus yang dihimpun oleh Dinas Kehutanan Sumatera Utara sudah mencapai 70 kasus illegal logging yang terjadi terdiri dari 33 kasus pada tahap penyilidikan, 21 kasus pada tahap penyidikan, 6 kasus yang telah dilimpahkan kepada kejaksaan, 5 kasus telah berada di pengadilan.

Pemerintah telah menetapkan UU 18 tahun 2013 tentang Pencegahan dan Pemberantasan Perusakan Hutan, dengan tujuan menjamin kepastian hukum dan memberikan efek jera bagi pelaku perusakan hutan serta menjamin keberadaan hutan secara berkelanjutan dengan tetap menjaga kelestarian dan tidak merusak lingkungan serta ekosistem sekitarnya. Ancaman pidana terhadap pembalakan liar diatur dalam pasal 82, yaitu dipidana dengan pidana penjara paling singkat 1 (satu) tahun dan paling lama 5 (lima) tahun serta pidana denda paling sedikit Rp. 500.000.000,00 (lima ratus juta rupiah) dan paling banyak Rp. 2.500.000.000,00 (dua miliar lima ratus juta rupiah bagi pelaku orang perseorangan, dan dipidana dengan pidana penjara paling singkat 5 (lima) tahun dan paling lama 15 (lima belas) tahun serta pidana denda paling sedikit Rp. 5.000.000.000,00 (lima miliar rupiah) dan paling banyak Rp. 15.000.000.000,00 (lima belas miliar rupiah) bagi pelaku korporasi (AFANDI, n.d.).

Kepolisian Republik Indonesia memiliki peran penting dalam penanggulangan tindak pidana pembalakan liar (Tuesang, 2009). Polisi sebagai aparat negara yang menjalankan fungsi penegakan hukum, pemeliharaan keamanan dan ketertiban masyarakat serta perlindungan, pengayoman dan pelayanan masyarakat, juga bertugas untuk mencegah dan menanggulangi tindak pidana pembalakan liar (Lamintang, 2013). Pada pasal 3 Undang-Undang Republik Indonesia Nomor 2 Tahun 2002 Tentang Kepolisian Negara Republik Indonesia menyebutkan bahwa Polri bertujuan mewujudkan tegaknya hukum. Polisi menempati posisi paling utama dalam penanggulangan tindak pidana karena bersinggungan secara langsung dengan masyarakat. Dengan jaringannya yang sangat luas hingga ke tingkat kecamatan, maka kepolisian lebih berkompetan dalam menanggulangi tindak pidana pembalakan liar dibanding lembaga penegak hukum lainnya, tetapi penanggulangan tindak pidana ini masih ada yang belum tersentuh oleh hukum yaitu adanya pembekingan oleh pejabat-pejabat sehingga menyulitkan penegakan hukumnya. Berdasarkan uraian tersebut diatas, maka penelitian ini bertujuan untuk mengkaji dan Wwiw $h t t p: / /$ mahesainstitute.web.id/ojs2/index.php/jehss N1. mahesainstitut@gmail.com 
menganalisis aturan hukum tentang tindak pidana perusakan hutan di Indonesia; Untuk mengkaji dan menganalisis faktor penyebab terjadinya pembalakan liar di wilayah hukum Polres Langkat; Untuk mengkaji dan menganalisis kebijakan yang dilakukan Kepolisian dalam penegakan hukum terhadap pembalakan liar di wilayah hukum Polres Langkat.

\section{METODE PENELITIAN}

Jenis penelitian yang dipergunakan dalam penelitian ini yaitu penelitian hukum normatif. Menurut Johnny Ibrahim, penelitian hukum normatif adalah suatu prosedur penelitian ilmiah untuk menemupakan kebenaran berdasarkan logika keilmuan dari sisi normatifnya. Sisi normatif disini tidak sebatas pada peraturan perundang-undangan saja (Ibrahim, 2013). Penelitian yuridis normatif bersifat deskriptif analisis, yaitu penelitian yang dilakukan dengan cara meneliti bahan pustaka (data sekunder) atau penelitian hukum perpustakaan (Ediwarman, 2016). Metode penelitian yang digunakan dalam penelitian ini adalah pendekatan pustaka dengan metode pendekatan kasus dan metode pendekatan perundang-undangan (statute approach) yaitu dilakukan dengan menelaah ketentuan perundang-undangan yang berlaku dalam kasus tersebut (Nawawi, H., 2015). Dari aspek lokasi penelitian, penelitian ini dilaksanakan di daerah Kabupaten Langkat dengan alasan di daerah ini terdapat banyak kasus pembalakan liar, dengan menjadikan Polres Langkat sebagai objek penelitiannya. Alat pengumpulan data yang dipergunakan adalah pedoman wawancara, yaitu suatu daftar yang memuat secara sistematis guna mendapatkan data dari informan. Analisis data dalam penelitian ini adalah secara kualitatif. Penarikan kesimpulan dilakukan dengan menggunakan metode induktif. Metode induktif artinya, dari data lapangan yang bersifat khusus yang telah diperoleh dari penelitian tentang pembalakan liar kemudian diambil kesimpulan yang bersifat umum (Tambunan, Dkk, 2019).

\section{HASIL DAN PEMBAHASAN \\ Faktor Penyebab Terjadinya Pembalakan Liar Di Wilayah Hukum Polres Langkat}

Salah satu aktivitas manusia yang mengakibatkan kerusakan lingkungan hidup adalah pembalakan liar atau illegal logging, yang merupakan tindakan eksploitasi oleh manusia terhadap hutan sehingga menimbulkan kerusakan terhadap ekosistem hutan. Pembalakan liar adalah semua kegiatan pemanfaatan hasil hutan kayu secara tidak sah yang terorganisasi yang berakibat pada kerusakan lingkungan hidup.

Pembalakan liar merupakan tindak pidana, karena penebangan yang dilakukan tidak didasarkan pada analisis dampak lingkungan, sehingga berdampak negatife terhadap lingkungan dan juga berdampak negative terhadap kehidupan manusia (Felia \& Kartika, 2020). Tetapi walaupun pembalakan liar telah dilarang, tetapi masih banyak terjadi pembalakan di berbagai tempat, dimana beberapa diantaranya telah menimbulkan bencana alam. Terjadinya pembalakan liar tentu karena didorong oleh berbagai factor baik faktor intern dan ekstern yang akan diuraikan sebagai berikut:

Faktor intern adalah faktor yang asalnya dari dalam diri seseorang atau individu itu sendiri. Pembalakan liar yang disebabkan faktor intern adalah:

1. Faktor Ekonomi. Faktor utama yang menyebabkan terjadinya pembalakan liar adalah keinginan untuk mendapatkan keuntungan besar dengan pengorbanan yang sekecil mungkin, yang disebut dengan motif ekonomi. Ada banyak orang yang berkeinginan mendapatkan untung besar dari hasil kayu hutan, walaupun dengan cara melanggar hukum. Pelaku dapat memperoleh hasilnya dengan cepat karena tinggal menebang kayu yang sudah ada, sehingga tidak perlu menunggu terlalu lama, dimana kayu hasil tebangan juga tergolong cepat lakunya di pasaran. Aktivitas yang dilakukan juga tidak banyak, cukup hanya membayar tenaga kerja sudah bisa mendapatkan banyak hasil kayu. Hal ini menyebabkan banyak orang tertarik untuk melakukan penebangan terhadap kayu hutan walaupun dengan risiko tertangkap oleh aparat penegak hukum.

2. Kurangnya Kesadaran Masyarakat terhadap Lingkungan. Masih banyak anggota masyarakat kurang menyadari dampak dari penebangan liar, sehingga mereka tidak terlalu perduli akibat yang ditimbulkannya, dan bahkan mereka terlibat secara langsung dalam aksi penebangan liar,

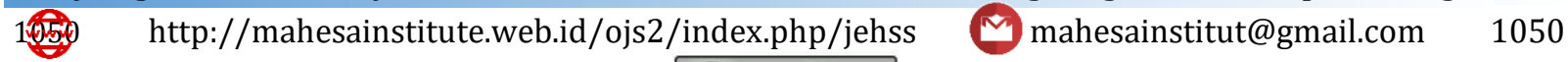

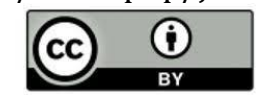


baik sebagai pelaku utama maupun sebagai tenaga kerja yang memperoleh bayaran. Rendahnya kesadaran masyarakat di sekitar lingkungan dekat hutan maupun di daerah kota menjadi faktor penyebab terjadinya pembalakan liar, karena mereka yang sehari-harinya dapat mengawasi hutan tidak melakukan partisipasi dengan melaporkan segala bentuk pembalakan, hal ini karena sebagian besar orang akan kurang perduli terhadap kemungkinan terjadinya bahaya bencana sebelum bencana tersebut benar- benar terjadi. Pada sisi lain pelaku pembalakan liar juga kurang menyadari bahwa lingkungan hutan adalah untuk kepentingan bersama, serta hanya memperdulikan kepentingan jangka pendek, yaitu memperoleh keuntungan yang besar.

Faktor ekstern adalah faktor penyebab perubahan sosial yang berasal dari luar lingkup masyarakat itu sendiri. Pembalakan liar yang disebabkan faktor intern adalah:

1. Harga Kayu Mahal. Faktor lain yang mendorong keinginan para pelaku dalam mengeksploitasi hasil hutan adalah tingginya harga kayu di pasar. Harga jual kayu semakin lama semakin meningkat sehingga keuntungan yang diperoleh juga semakin besar. Faktor lain yang mendorong pelaku menjadikan kayu hutan sebagai sasaran tindak pidana adalah harga kayu yang relatif makal, sehingga dengan penjualan beberapa ton kayu saja dapat diperoleh keuntungan hingga puluhan juta rupiah. Ini tentu sangat menggiurkan terlebih bagi orangorang yang hanya mementingkan keuntungan jangka pendek. Objek kayu hutan sebagai sasaran tindak pidana penebangan liar akan semakin marak terjadi seiring dengan semakin tingginya harga kayu hutan, terlebih hingga saat ini belum ada bahan lain yang dapat menggantikan peran kayu hutan.

2. Kebutuhan Kayu Tinggi. Persediaan kayu semakin menipis padahal kebutuhan terhadap kayu hutan justru semakin meningkat seiring dengan semakin bertambahnya jumlah penduduk. Peran kayu belum tergantikan oleh bahan lain sehingga kebutuhan terhadap kayu akan tetap semakin tinggi, dan hal ini akan semakin mendorong terjadinya tindak pidana penebangan liar. Tingginya kebutuhan kayu menyebabkan penebangan liar juga terjadi, terlebih karena izin penebangan terhadap kayu tidak mudah diperoleh, karena pemerintah telah memiliki program untuk melestarikan hutan sebagai penyangga bagi lingkungan alam. Padahal pada sisi lain kebutuhan terhadap kayu akan terus mengalami peningkatan seiring dengan peningkatan jumlah penduduk. Jika terjadi kelangkaan kayu dipasaran maka orang akan terdorong memperolehnya walaupun dengan cara melakukan tindak pidana penebangan liar. Disamping itu, kebutuhan kayu untuk ekspor juga masih tetap tinggi, dan harga yang ditawarkan juga relatif lebih mahal dibanding dengan pasar dalam negeri.

3. Pengawasan Yang Lemah. Pengawasan yang lemah dari penegak hukum khususnya petugas kepolisian menjadi penyebab lain dari terjadinya penebangan liar, dimana orang-orang atau pelaku semakin leluasa melakukan aksi kejahatannya. Aparat kepolisian kurang berperan dalam melakukan pengawasan terhadap hutan atau lokasi pinggir hutan, padahal pelaku justru melakukan aksinya jauh di dalam hutan, dimana alat-alat atau mesin yang digunakan tidak terdengar sampai dari pinggir hutan. Hal ini menyebabkan aksi penebangan oleh pelaku semakin leluasa. Dalam beberapa kasus, kepolisian hanya menerima laporan dari masyarakat sehingga jarang mengetahui aktivitas penebangan liar di hutan. Tindakan pengawasan paling tinggi hanya sebatas merazia truk-truk pengangkut kayu, yang kemungkinan besar justru sudah memiliki izin pengangkutan, walaupun mungkin kayu yang dibawanya juga sebenarnya adalah hasil dari penebengan liar.

Penegakan hukum yang kurang tegas juga dapat mendorong terjadinya penebangan liar, dimana para pelaku merasa akan mudah melepaskan diri dari jeratan hukum pidana. Penegakan hukum terhadap pelaku pembalakan liar masih tergolong lemah, mungkin karena pelaku sangat mudah mempengaruhi para pejabat atau penegak hukum dengan kekuatan finansialnya yang relatif besar. Banyak kasus yang ditangani oleh kepolisian kemudian tidak ditindaklanjuti sehingga pelaku lepas dengan mudah dari penegakan hukum. Kasus-kasus yang sampai kepersidangan juga sering di vonis terlalu ringan sehingga pelaku merasa tidak terlalu takut dengan hukum. Hal ini juga didukung dengan kemungkinan adanya beking yang melakukan intervensi terhadap proses hukum, sehingga pelaku menjadi lebih mudah lepas dari jangkauan hukum. 
Selanjutnya faktor-faktor penyebab terjadinya pembalakan liar tersebut memberikan dampak yang relatif besar terhadap kerusakan lingkungan hidup, bahkan sering menjadi sumber gangguan bagi kehidupan masyarakat yang berada di sekitar hutan dimana pembalakan liar sering terjadi. Adapun dampak yang ditimbulkan dari terjadinya pembalakan liar adalah sebagai berikut:

1. Banjir Pada Saat Musim Penghujan. Penebangan liar telah dinyatakan sebagai faktor penyebab utama terjadinya banjir sungai dalam skala besar dalam suatu daerah, karena keberadaan kayu sebagai penyerap air hujan sudah semakin menipis, sehingga semua air hujan langsung meluap ke sungai hingga melewati daya tamping sungai. Kebanjiran sering melanda Kabupaten Langkat, dimana penggundulan hutan sebagai akibat pembalakan liar dinyatakan sebagai faktor penyebab utamanya. Air yang meluap terlalu tinggi menyebabkan tanggul jebol dan air mengalir hingga ke rumah warga. Disamping itu, ratusan hektar sawah juga terendam banjir sehingga menyebabkan gagal panen, yang berarti menyebabkan kerugian besar kepada para petani. Aktivitas penebangan liar sama sekali tidak memperhitungkan atau mempertimbangkan dampak lingkungan yang ditimbulkannya, karena tidak melalui analisis dampak lingkungan. Hal ini berbeda dengan penebangan yang memiliki izin, tentu telah didasari pada hasil analisis bahwa penebangan di daerah tersebut tidak akan berdampak negative terhadap lingkungan masyarakat, dan segera akan dihijaukan kembali.

2. Mengganggu Kehidupan Satwa Liar. Satwa liar telah menjadi hewan yang dilindungi oleh negara, dimana perlindungan tersebut diberikan bukan hanya melindungi dari perburuan oleh manusia, tetapi juga menjamin terpeliharanya habitat hidup satwa liar. Hutan merupakan habitat berbagai jenis satwa liar yang dilindungi, tetapi jika terjadi penebangan liar maka akan menyebabkan satwa liar terganggu, sehingga satwa liar keluar dari hutan dan mengganggu kehidupan warga. Dampak dari pembalakan liar telah merugikan warga di sekitar hutan, karena satwa liar yang dilindungi oleh negara keluar dari hutan dan mengusik kehidupan warga. Sudah banyak ternak seperti lembu yang dimangsa harimau di daerah ini sehingga warga menjadi lebih hati-hati menjaga ternaknya. Disamping itu warga juga menjadi lebih takut untuk keluar rumah apalagi jika dekat dengan hutan, karena sewaktu-waktu takut bertemu dengan harimau yang keluar dari hutan mencari mangsa. Penebangan liar menyebabkan ekosistem hutan terganggu sehingga hewan pemangsa kekurangan makanan, dan akibatnya hewan pemangsa seperti harimau mencari makanan di luar hutan.

3. Menyebabkan Cadangan Air Menipis. Hutan dengan pohon-pohon yang lebat merupakan pengikat air yang cukup digunakan sebagai persediaan air bagi warga. Tetapi dengan penebangan liar maka pohon akan berkurang dan cadangan air juga akan menjadi semakin berkurang. Penebangan liar menyebabkan warga kesulitan air akibat hutan yang semakin gundul, padahal kebutuhan air tidak hanya kebutuhan rumah tangga tetapi juga dibutuhkan oleh tanaman di ladang atau sawah. Jumlah akar-akar pohon yang menahan air semakin sedikit sehingga cadangan air di hutan semakin rendah, akibatnya air sungai menjadi menyusut pada musim kemarau, tetapi meluap pada musim hujan. Penebangan liar menyebab dampak yang luar biasa terhadap kehidupan warga, khususnya warga di sekitar hutan.

\section{Kebijakan Yang Dilakukan Kepolisian Dalam Penegakan Hukum Terhadap Pembalakan Liar Di Wilayah Hukum Polres Langkat}

Kepolisian Resor Langkat memiliki peran penting dalam penanggulangan tindak pidana pembalakan liar. Polisi sebagai aparat negara yang menjalankan fungsipenegakan hukum, pemeliharaan keamanan dan ketertiban masyarakat serta perlindungan, pengayoman dan pelayanan masyarakat, juga bertugas untuk mencegah dan menanggulangi tindak pidana pembalakan liar. Pada pasal 3 Undang-Undang Republik Indonesia Nomor 2 Tahun 2002 Tentang Kepolisian Negara Republik Indonesia, menyebutkan bahwa Polri bertujuan mewujudkan tegaknya hukum. Polisi menempati posisi paling utama dalam penanggulangan tindak pidana karena bersinggungan secara langsung dengan masyarakat. Dengan jaringannya yang sangat luas hingga ke tingkat kecamatan, maka kepolisian lebih berkompetan dalam menanggulangi tindak pidana pembalakan liar dibanding lembaga penegak hukum lainnya. Artinya kebijakan kepolisian 
yang diterapkan oleh kepolisian sangat berperan penting dalam penanggulangan pembalakan liar di Kabupaten Langkat.

Kebijakan Kepolisian Resor Langkat dalam penegakan hukum terhadap tindak pidana pembalakan liar adalah kebijakan penal dan non penal. Kebijakan penal adalah kebijakan dengan memberdayakan Sistem Peradilan Pidana atau Criminal Justice System (penegakan hukum pidana) (Chairul, 2015), sedangkan kebijakan non penal adalah menangani dan menghapuskan faktorfaktor kondusif yang menyebabkan terjadinya suatu tindak pidana, mempunyai sifat pencegahan sebelum terjadinya tindak pidana (Muladi dan Nawawi Arif, 2005).

Kebijakan penal dilakukan kepolisian terhadap pelaku yang telah terlibat dalam tindak pidana penebangan liar. Semua pelaku ditindak sesuai dengan hukum yang berlaku, yang dimulai dari adanya laporan, menindaklanjuti laporan, olah TKP, mengamankan barang bukti, melakukan penangkapan, pengembangan perkara, kemudian penyerahan berkas ke jaksa penuntut. Tahapan tersebut akan dijelaskan sebagai berikut:

1. Laporan Pembalakan Liar. Langkah pertama yang dilakukan kepolisian dalam penegakan hukum adalah dengan menerima laporan, baik dari masyarakat maupun dari hasil penyelidikan anggota kepolisian. Pada dasarnya kepolisian jarang menerima laporan dari masyarakat atas aktivitas penebangan liar yang dilakukan oleh pembalak liar. Masyarakat baru membuat laporan jika aktivitas pembalakan liar tersebut telah menimbulkan dampak serius terhadap kehidupan mereka, seperti berkurangnya sumber air atau adanya kebanjiran pada saat musim hujan. Berdasarkan informasi tersebut juga dapat dijelaskan bahwa sebagian besar kasus yang ditangani kepolisian bersumber dari hasil penyelidikan oleh kepolisian, dimana anggota kepolisian juga secara aktif mengalami aktivitas yang terdapat disekitar hutan, walaupun pengamatan tersebut tidak memungkinkan untuk dilakukan langsung ke dalam hutan.

2. Menindaklanjuti Laporan Pembalakan Liar. Langkah berikutnya dalam penegakan hukum yang dilakukan oleh kepolisian adalah dengan menindaklanjuti laporan. Tindak lanjut laporan yang paling utama adalah mempelajari laporan agar kepolisian tidak salah dalam bertindak. Tindakan kepolisian tergantung pada hasil penelusuran terhadap laporan yang diberikan oleh masyarakat atas pembalakan liar yang terjadi di wilayah mereka. Dalam hal ini kepolisian tidak boleh bertindak gegabah karena dapat dianggap menyalahi prosedur sehingga dianggap sebagai pelanggaran hukum. Berdasarkan pengalaman, banyak laporan dari masyarakat yang tidak didasarkan pada fakta yang jelas di lapangan, atau mungkin juga kejadiannya telah lama berlalu, sehingga kepolisian kehilangan kesempatan untuk melakukan pembuktian. Tetapi terhadap perkara yang merupakan hasil pengamatan langsung kepolisian, dapat segera ditindaklanjuti dengan terjun ke lapangan melakukan penangkapan.

3. Terjun ke Lokasi Pembalakan Liar. Tindakan penyergapan terhadap pelaku pembalakan liar merupakan tindakan lebih lanjut terhadap laporan yang terima oleh kepolisian. Dalam penyergapan tersebut akan dilakukan penangkapan terhadap setiap pelaku yang terlibat. Tindakan kepolisian untuk melakukan penggebrekan agan dilaksanakan dengan segera jika terdapat dugaan bahwa para pelaku masih berada di tempat atau di lokasi hutan, dan sedang melakukan aktivitas penebangan liar. Tetapi kadang terjadi bahwa orang-orang tersebut tidak lagi berada di tempat, dan hanya meninggalkan kayu-kayu yang sudah tumbang dan balokbalok yang siap untuk diangkut. Penggebrekan kadang tidak selalu berhasil menangkap pelaku secara langusung, karena para pelaku biasanya telah menempatkan mata-mata untuk mengamati pergerakan kepolisian, dimana dengan berkembangkan teknologi informasi akan semakin memudahkan mata-mata mengirimkan informasi kepada para pelaku, dari jarak jauh.

4. Mengamankan Barang Bukti. Barang bukti merupakan bagian penting dari penanganan perkara, dimana barang bukti tersebut merupakan petunjuk utama telah terjadinya tidak pidana. Oleh karena itu setiap barang bukti akan segera diamankan oleh petugas kepolisian, terutama pada saat petugas melakukan penyergapan. Pengamanan terhadap alat bukti akan segera dilakukan jika pada saat penggebrekan berhasil menemukan tersangka di tempat kejadian perkara. Tetapi jika tersangka berhasil melarikan diri, maka kemungkinan alat bukti seperti kayu gelondongan akan dibiarkan atau tidak diamankan, tetapi tetap dipantau terus 
menerus, dengan harapan agar tersangka atau pekerjanya datang ke tempat kejadian perkara, yang kemudian segera dilakukan penangkapan. Alat bukti yang biasanya ditemukan kepolisian dalam perkara pembalakan liar adalah mesin sinso dan kayu, atau mungkin juga alat transportasi para pelaku jika ada di tempat kejadian perkara.

5. Menangkap Truk Kayu Illegal. Penindakan terhadap truk kayu illegal juga merupakan bagian dari tindakan represif terhadap para pelaku pembalakan liar. Kayu yang diangkut tanpa izin biasanya berasal dari pembalakan liar, sehingga kepolisian akan bertindak dengan tegas. Kepolisian juga melakukan tindakan represif terhadap truk pengangkut kayu yang tidak dapat meninjukkan izin angkut, dan besar kemungkinan bahwa kayu tersebut berasal dari hasil pembalakan liar. Truk akan diamankan bersama supir dan kernet truk untuk melakukan pemeriksaan lebih lanjut, dimana dari pengalaman kepolisian bahwa keterangan supir dan kernet biasanya dapat mengarahkan kepolisian untuk mengetahui pemilik kayu illegal tersebut. Kepolisian akan segera melakukan pengejaran terhadap pemilik kayu sebelum melarikan diri, dan kemudian ditangkap untuk penyidikan lebih lanjut.

Selanjutnya kebijakan non penal menjadi sangat populer belakangan ini karena kebijakan tersebut dianggap lebih efektif, dimana kerusakan terhadap hutan dapat dicegah sebelum terjadi (Mardjono, 2014). Dalam kebijakan non penal, maka kepolisian akan lebih fokus mengatasi halhal yang menyebabkan warga melakukan penebangan liar di hutan yang terdapat Kabupaten Langkat. Berbagai tindakan kebijakan non penal yang telah dilakukan oleh kepolisian seperti melakukan sosialisasi, meningkatkan partisipasi masyarakat, serta mengawasi truk-truk kayu yang melintas di jalan raya.

Sosialisasi dilakukan untuk memberitahukan kepada warga mengenai adanya larangan terhadap penebangan liar. Banyak warga masyarakat yang masih belum mengetahui bahwa terdapat larangan untuk melakukan penebangan secara sembarangan terhadap kayu hutan, bahkan beberapa menganggap bahwa mereka berhak karena itu adalah hutan mereka (Siallagan, Dkk, 2017). Kepolisian melakukan sosialisasi dengan memberikan pengarahan kepada warga agar tidak melakukan penebangan terhadap kayu secara sembarangan. Hal ini karena masih banyak warga yang tidak mengetahui larangan penebangan liar, atau juga banyak warga yang tidak memahami terdapat penebangan yang diizinkan padahal mereka tidak boleh menebang kayu hutan. Kepolisian memberikan pengarahan mengenai larangan penebangan secara sembarangan serta menegaskan akibat hukum yang akan diterima oleh pelaku penebangan liar.

Masyarakat yang berada disekitar hutan merupakan bagian penting dari kebijakan preventif yang dilakukan kepolisian, karena masyarakat yang sehari-harinya beraktivitas di lokasi sekitar hutan dapat mengamati lebih baik terhadap kemungkinan adanya penebangan liar. Oleh karena itu kepolisian berupaya meningkatkan partisipasi masyarakat. Kepolisian telah berupaya meningkatkan partisipasi masyarakat sebagai sumber informasi terhadap segala aktivitas pelanggaran hukum yang terjadi terhadap kayu hutan. Masyarakat diminta segera membuat laporan jika melihat adanya penebangan liar, dimana laporan dapat juga diberikan melalui telepon langsung ke petugas Polres Langkat. Kepolisian sangat menyadari pentingnya melibatkan masyarakat untuk mengawasi hutan terhadap kemungkinan adanya pembalakan liar, karena orang-orang yang sehari-harinya berada disekitar hutan tentu dapat dengan mudah mengetahui jika ada penebangan liar terhadap kayu hutan.

Tindakan preventif kepolisian berupaya pengawasan juga dilakukan, yaitu mengawasi atau melakukan razia terhadap truk-truk yang mengangkut kayu, karena banyak diantara mereka tidak memiliki izin angkut kayu karena sumber kayunya adalah hasil penebangan liar. Kepolisian melakukan pengawasan dalam bentuk razia terhadap truk-truk yang melakukan pengangkutan kayu, untuk mencegah adanya pengangkutan kayu illegal. Hal ini karena kayu illegal hasil penebangan liar biasanya diangkut tanpa izin angkut, dimana dengan pengawasan yang intentif diharapkan masyarakat menjadi tidak sembarangan melakukan penebangan liar, karena pengangkutannya di wilayah Polres Langkat relatif sulit dilakukan, dimana besar kemungkinan akan terkena razia. Pengawasan terhadap truk kayu juga dilakukan pada malam hari, karena berdasarkan pengalaman kepolisian justru pelaku penebangan liar memanfaatkan jam sepi, yaitu dari tengah malam hingga pagi hari untuk mengangkut kayu hasil tindak pidana yang dilakukan. 
Pemeriksaan terhadap tersangka merupakan tindakan represif yang paling penting, karena keterangan atau pengakuan tersangka atas keterlibatannya dalam penebangan liar, serta hubungannya dengan alat-alat bukti lainnya merupakan fakta hukum yang kuat. Tindakan represif berupa penegakan hukum juga mencakup pemeriksaan terhadap tersangka yang telah ditangkap (Harie, 2009). Pemeriksaan ditujukan untuk meminta keterangan dari tersangka sehubungan dengan keterlibatannya dalam pembalakan liar, serta hubungannya dengan alat-alat bukti fisik yang telah diamankan kepolisian. Keterangan tersangka juga akan dikonfrontir dengan keterangan terasangka lainnya untuk meyakinkan keterangan dari tersangka.

Pengembangan kasus merupakan bagian penting dari penyidikan terhadap tindak pidana pembalakan liar, karena biasanya pelaku utamanya tidak terlibat secara langsung di lapangan. Kepolisian tidak mudah menemukan tersangka utama yang berperan dalam pembalakan liar, karena yang ditangkap biasanya adalah orang-orang suruhan atau pun bawahannya. Pengembangan kasus memang dapat mengarahkan kepolisian terhadap tersangka utama, tetapi jika tersangka utamanya adalah orang penting, maka penangkapan akan sulit dilakukan. Hal ini sering menjadi kendala dalam penegakan hukum terhadap pembalakan liar.

Pelimpahan berkas perkara dan tersangka merupakan bagian akhir dari penegakan hukum pada tingkat kepolisian. Dalam hal ini berkas perkara hasil penyidikan di kepolisian yang sudah dinyatakan P-21 diserahkan kepada jaksa penuntut umum beserta tersangka pelaku tindak pidana pembalakan liar. Proses penyidikan hingga berkas dinyatakan P-21 dalam perkara pembalakan liar dapat dilakukan dalam waktu yang tepat, dalam arti tidak melampaui batas waktu yang ditetapkan oleh UU, yaitu 60 hari. Walaupun kadang jaksa penuntut umum melakukan pengembalian berkas selama proses penyidikan, tetapi hal-hal yang diminta jaksa penuntut untuk dilengkapi biasanya dapat dipenuhi dengan cepat, sehingga penyerahan berkas perkara dan tersangka dan berkas perkara oleh penyidik ke jaksa penuntut umum dapat dilakukan dengan cepat.

\section{SIMPULAN}

Perusakan hutan akibat pembalakan liar tentu akan mengganggu lingkungan hidup, karena hutan memiliki peran penting sebagai paru-paru dunia, habitat flora dan fauna, serta pengendali bencana. Pembalakan liar merupakan tindak pidana, karena penebangan yang dilakukan tidak didasarkan pada analisis dampak lingkungan, sehingga berdampak negatif terhadap lingkungan dan juga berdampak negative terhadap kehidupan manusia. Terjadinya pembalakan liar didorong oleh berbagai faktor baik faktor intern dan ekstern. Faktor-faktor penyebab terjadinya pembalakan liar tersebut memberikan dampak yang relatif besar terhadap kerusakan lingkungan hidup, bahkan sering menjadi sumber gangguan bagi kehidupan masyarakat yang berada di sekitar hutan dimana pembalakan liar sering terjadi. Perlunya kebijakan kepolisian yang diterapkan oleh kepolisian sangat berperan penting dalam penanggulangan pembalakan liar di Kabupaten Langkat. Kebijakan Kepolisian Resor Langkat dalam penegakan hukum terhadap tindak pidana pembalakan liar adalah kebijakan penal dan non penal. Kebijakan penal dilakukan kepolisian terhadap pelaku yang telah terlibat dalam tindak pidana penebangan liar. Semua pelaku ditindak sesuai dengan hukum yang berlaku, yang dimulai dari adanya laporan, menindaklanjuti laporan, olah TKP, mengamankan barang bukti, melakukan penangkapan, pengembangan perkara, kemudian penyerahan berkas ke jaksa penuntut sedangkan kebijakan non penal yang dilakukan oleh kepolisian Resor Langkat seperti melakukan sosialisasi, meningkatkan partisipasi masyarakat, serta mengawasi truk-truk kayu yang melintas di jalan raya. 


\section{DAFTAR PUSTAKA}

Afandi, A. (N.D.). Penyertaan Dalam Tindak Pidana Perusakan Hutan Berdasarkan Undang-Undang Nomor 18 Tahun 2013 Tentang Pencegahan Dan Pemberantasan Perusakan Hutan. Tadulako University.

Armawi, A. (2013). Kajian Filosofis Terhadap Pemikiran Human-Ekologi Dalam Pemanfaatan Sumberdaya Alam (Philosophical Studies Of Human Ecology Thinking On Natual Resource Use). Jurnal Manusia Dan Lingkungan, 20(1), 57-67.

Ediwarman, (2016), Monograf Metode Penelitian Hukum (Panduan Penulisan Skripsi, Tesis, Dan Disertasi), Genta Publishing, Medan

Felia, S., \& Kartika, F. B. (2020). Tindak Pidana Illegal Logging Ditinjau Dari Perspektif Undang-Undang No 32 Tahun 2009 Tentang Perlindungan Dan Pengelolaan Lingkungan Hidup. Jurnal Lex Justitia, 1(2), 186195.

Huda, C, (2015), Dari Tiada Perbuatan Tanpa Kesalahan Menuju Kepada Tiada Pertanggungjawaban Pidana Tanpa Kesalahan, Kencana, Jakarta.

Lamintang, P.A.F., (2013), Dasar-Dasar Hukum Pidana Indonesia, Citra Aditya Bakti, Bandung

Nawawi, H., (2015), Metode Penelitian Bidang Sosial, Gadjah Mada University Press, Yogyakarta.

Nawawi, A.B., (2016), Bunga Rampai Kebijakan Pidana, Citra Aditya Bakti, Bandung.

Prabowo, T. F. P. P., \& Absori, A. (2018). Kebijakan Hukum Pariwisata Di Bidang Lingkungan. Tugas Kuliah, 1-19.

Rahman, A., \& Mulada, D. A. (2020). Pemungutan Hasil Hutan Negara. Jatiswara, 35(3).

Reksodiputro, M, (2014), Sistem Peradilan Pidana (Peran Penegak Hukum Melawan Kejahatan), Pusat Pelayanan Keadilan Dan Pengabdian Hukum, Universitas Indonesia, Jakarta.

Rosana, M. (2018). Kebijakan Pembangunan Berkelanjutan Yang Berwawasan Lingkungan Di Indonesia. Kelola: Jurnal Sosial Politik, 1(1), 148-163.

Salman, O., \& Susanto, A.F., (2005), Teori Hukum, Mengingat, Mengumpulkan Dan Membuka Kembali, Refika Aditama, Bandung.

Siallangan, A.F, \& Siregar, T. (2017). Peranan Kantor Pengawasan Dan Pelayanan Bea Dan Cukai Belawan Dalam Penanggulangan Penyelundupan Satwa Dilindungi Jurnal Ilmiah Penegakan Hukum, 4 (1) 2017: 1-7

Siregar, F. Y. D. (2020). Aspek Hukum Penyederhanaan Perizinan Badan Usaha Di Bidang Lingkungan Hidup Dalam Undang-Undang Cipta Kerja. Jurnal Ilmiah Penegakan Hukum, 7(2), 184-192.

Sunarso, S, (2015), Hukum Pidana Lingkungan Hidup Dan Strategi Penyelesaian Sengketa, Rineka Cipta, Jakarta.

Tuesang, H, (2009), Upaya Penegakan Hukum Dalam Era Reformasi, Restu Agung, Jakarta.

Tambunan, R, Suhatrizal \& Siregar, T. (2019). Penegakan Hukum Terhadap Tindak Pidana Kepabean Penyeludupan Pakaian Bekas (Putusan No. 237/Pid.B/2016/PN. Tjb). JUNCTO, 1(2) 2019: 158-165,

Undang-Undang No. 41 Tahun 1999 Tentang Kehutanan

Undang-Undang Nomor 32 Tahun 2009 Tentang Perlindungan Dan Pengelolaan Lingkungan Hidup.

Undang-Undang Nomor 18 Tahun 2013 Tentang Pencegahan Dan Pemberantasan Perusakan Hutan.

Kitab Undang-Undang Hukum Pidana (Kuhp)

Kitab Undang-Undang Hukum Acara Pidana (Kuhap) 